\title{
UČENJE ČITANJA I STRATEGIJE U RANOM POUČAVANJU
}

\author{
Simona Mlaker Šušek \\ Osnovna škola bratov Polančičev, Maribor, Slovenija
}

\begin{abstract}
Sažetak
Suvremeno planiranje nastave temelji se na komunikacijskoj nastavi. Naglašava se važnost okoline za učenje u kojoj se formiraju socijalne kompetencije učenika. Te kompetencije počinju se razvijati u ranoj dobi, a na početku školovanja već se izražavaju kao primjetljive osobne karakteristike. U radu se opisuje primjer iz prakse, kako tijekom nastave upotrebljavati različite nastavne strategije za stjecanje novog znanja. U okviru projekta Inovativna pedagoška vježbenica Osnovne škole bratov Polančičev iz Maribora svake godine planiramo, provodimo i evalviramo inovativne pristupe pedagoške prakse. Uvjereni smo da je kod odgojno-obrazovnog rada nužno spajanje teorijskih i praktičkih iskustava. U ovoj školskoj godini osobito smo se usmjerili na učenje čitanja i na strategije u ranom poučavanju.
\end{abstract}

Ključne riječi: istraživačko učenje, okolina učenja, otvorena nastava, međupredmetno planiranje nastave, međuvršnjačka suradnja

\section{UvoD}

Vrijeme, društvene promjene, nova stručna razmišljanja, bez sumnje ostavljaju trag i u životu i radu škole. Zbog toga se u pedagoškom prostoru u cikličkim razdobljima otvaraju poznate teme kao što su unapređenje nastavnih planova, cjeloživotno obrazovanje i čitalačka pismenost. Upravo je područje čitalačke pismenosti težište stručnih ali i manje stručnih diskusija. Laici je obično povezuju samo s čitanjem i razumijevanjem pročitanog teksta, a pedagoški radnici znaju da taj proces uključuje mnogo više od toga.

Okolina za učenje dodirna je točka brojnih istraživačkih nastojanja, mišljenja i iskustava. U njoj se sreću učenici, učitelji, njihovi roditelji, različiti stručnjaci i mnogi drugi ljudi kojima se čini da nešto znaju o školi. Vrijeme i promjene koje nastaju isto tako utječu na procese u školi iako se čini da škola uspješno prkosi "modnim zahtjevima“ modernog doba i promišljeno bira što smije i što ne smije doći do učionica i učenika.

Škola je osjetljiva na procese koji se odvijaju izvan i unutar nje. Na njih se odazivamo na različite načine i različitim interesima. Kao ocenjivači pedagoškog procesa u nju ulaze intelektualne elite, politički ideolozi i civilno društvo odnosno javnost.

$\mathrm{U}$ otvorenoj učionici u kojoj se nitko ne skriva iza zatvorenih vrata razreda nužne su i pluralnost pedagoških koncepata i autonomija učitelja u njihovoj implementaciji.

Edukativne znanosti u svijetu u proteklih dva desetljeća ponudile su izuzetna otkrića o procesima učenja. Stoga usporedba da se još uvijek radi o „black box“ više nije opravdana. Potvrđuje se, pak, da je učenje vrlo kompleksna aktivnost koju nije moguće razumjeti te u njoj djelovati djelomice i nepovezano. Isto tako, nužno je spojiti teorijska i praktička nastojanja jer se tek tada razotkriju sve dimenzije pedagoškog problema koji rješavamo. Učenje se događa u neposrednoj okolini za učenje i samo unutar nje može se utvrditi koji pedagoški modeli, strategije, oruđe itd. zaista djeluju. 
TEORIJSKI I PRAKTIČNI PROBLEMI I RASPRAVE

Otvorenu ili aktivnu nastavu odlikuju neke karakteristike među kojima stručnjaci navode da:

1. nastavni ciljevi, sadržaji i metode nisu točno određeni (Martenič Požarnik, 2000)

2. difrencijacija i individualizacija učenicima omogućuje suradnju (Strmčnik, 2003)

3. se nastava usmjerava „prema učeniku” i sve manje „prema učitelju” i nastavnoj materiji (Cvetek, 2004)

4. omogućuje aktivno učenje (Marentič Požarnik, 2000)

5. učenici uče u konkretnim okolinama za učenje koje ih zaokupljaju na misaonom, emocionalnom i vrijednosnom području (Kružnik, 2008).

Spomenute spoznaje dovele su do promjena u području poimanja znanja, poučavanja i učenja. Naglašava se kompleksno i dinamičko znanje, učenje se shvaća kao proces, a poučavanje se shvaća kao stvaranje situacija za otkrivanje i izgradnju znanja (Plut Pregelj, 2005).

Usvajanje znanja dakle nije transmisija znanja, pamćenje podataka, nego konstruiranje, inoviranje i samostalno objašnjivanje podataka. Tijekom takvog nastavnog procesa učenik je usredotočen jer se važnost pridaje idejama i aktivnostima učenika te upoznavanju pojava pomoću vlastitog misaonog napora (Hus, 2002). Nastavni proces teži kvaliteti zato učitelj izbjegava masovnu upotrebu tradicionalnih didaktičkih strategija jer konstruktivno učenje danas više ne znači „guranje informacija u glave učenika“, nego izgradnju, tj. konstrukciju znanja uz samoinicijativno djelovanje (Marentič Požarnik i Cencič, 2004).

Ali takvi pokušaji zahtijevaju profesionalni pristup učiteljica, promijenjenu ulogu učenika i klimu poučavanja u razredu, odmjerenu podršku školskog rukovodstva i uvjerenost roditelja da je to pravi put do više razine konstruiranja znanja učenika, a što je i glavni cilj svih nastojanja.

Čitalačka pismenost određuje se kao trajno razvijajuća sposobnost pojedinaca da upotrebljava društveno dogovorene sustave simbola za stvaranje, razumijevanje i korištenje tekstova za potrebe života u obitelji, školi, na radnom mjestu i u društvu.

Osnovu za učinkovito usvajanje pismenosti, tj. učenje čitanja i pisanja, predstavljaju dobro razvijene sposobnosti (meta)jezične svijesti. U prvi razred ubrajamo sposobnost osviještenosti jezičnih struktura, sposobnost slušne distinkcije te sposobnost vidne distinkcije. To su ključne sposobnosti koje djetetu omogućuju brzi napredak u učenju čitanja i pisanja u drugom razredu. Istodobno, uz razvoj navedenih sposobnosti razvijamo i sposobnost distinkcije slušanja i govora; učenik, naime, nacrtane predmete imenuje, o njima priča, objašnjava i argumentira svoja rješenja (Pečjak,2000).

Svjesni smo da je čitalačka pismenost učenika osnova za njihovo daljnje obrazovanje, za studij, za djelovanje na stručnom području i šire, za rad u društvu. U školu dolaze učenici različitog predznanja, ponašanja i različitih sposobnosti. U mislima posebno moramo imati učenike koji postižu lošiji školski uspjeh, kojima učinkovito čitanje predstavlja još veću prepreku. Ako u školi želimo razvijati pismenost, moramo razvijati i različite metode i oblike poučavanja pismenosti. Noviji oblici poučavanja proširuju ulogu učitelja. Ako učenicima ne pomažemo sustavno osvještavati osobnu ulogu u aktivnostima čitanja i na tom stupnju razviti kritičke sposobnosti čitanja, učenici neće razviti dovoljnu pismenost za uspješno djelovanje u 21. stoljeću (Grosman, 2006).

Dakle, postavlja se pitanje na koji način oblikovati nastavu čitanja u školi kako bi učenici postali pismeni čitatelji. Teoretičari smatraju da tome vodi cjelovita nastava čitanja, i to $u$ kombinaciji s aktivnostima iz djetetova stvarnog života kako bi dijete upoznalo čitanje u funkciji. Učenik mora razumjeti poruke za vrijeme čitanja i slušanja te u govoru i pisanju biti sposoban oblikovati razumljive poruke. 


\section{Jednostavna strategija čitanja u ranom poučavanju}

Konačni je cilj učenja čitalačko razumijevanje gradiva. Razumijevanje je aktivan proces u kojem čitatelj pokušava interpretirati pročitano, a pomoću "mosta” pokušava povezati nove informacije s onima koje već ima. Govorimo o procesu integriranja novih informacija u postojeću kognitivnu shemu (Ošlak, 2009).

$\mathrm{U}$ prilogu predstavljamo dio nastavnog procesa u drugom razredu gdje učenici na primjeru usvajanja neumjetničkog teksta o bubamari razvijaju pet kognitivnih procesa:

(1) kognicija - spoznaja i prepoznavanje informacija iz teksta;

(2) pamćenje - zadržavanje i pohrana informacija;

(3) konvergentno mišljenje - zaključivanje;

(4) divergentno mišljenje - logičke, kreativne i stvaralačke ideje i

(5) kritičko mišljenje - vrednovanje teksta.

Pritom već uče kako postavljati ciljeve, kriterije te vrednovati svoj rad. Učenici znaju da čitanjem neumjetničkih tekstova usavršavaju čitanje, šire vokabular, traže nove spoznaje, a rješavanjem zadataka potvrđuju i razumijevanje teksta.

Zadani zadatak izveden je na tri stupnja. Planiranju učenja i određivanju ciljeva slijedilo je samostalno učenje i na kraju zajednička refleksija.

\section{Planiranje učenja i određivanje ciljeva}

Prvi stupanj namijenjen je svim učenicima. Odvija se frontalno kada učenike navodimo na samostalno planiranje vremena, učenja i određivanje ciljeva. Zbog toga imaju posebno pripremljene radne listove koji im pomažu upoznati korake jednostavne strategije učenja s tzv. kognitivnom mapom.

Učenici su bili upoznati s temom učenja. Znali su da će učiti o kukcu bubamari. Predstavljen im je put učenja, ciljevi, kriteriji i plan rada koji su samik izradili uz pomoć učitelja. Put učenja bio je zapisan prema sljedećim koracima:

- Napisat ću što znam o bubamari.

- Zapisat ću pitanja što me o bubamari još zanima.

- Pročitat ću tekst o bubamari na listu/udžbeniku.

- Detaljno ću pogledati sliku te životinje.

- Dopunit ću znanje o bubamari.

- Zapamtit ću nove spoznaje.

- U DZ ću provjeriti koliko sam naučio.

Slijedio je pregled i izbor ciljeva uz poštivanje određenih kriterija. Pritom je od izrazitog značenja to da učenici znaju i razlikuju puta učenja, opis aktivnosti i ciljeve. Važna je pravilna formulacija cilja. Pritom često dolazi do nepravilnog određivanja cilja. Ako zapišemo:

- „Izvest ću aktivnost prema planu“, time opisujemo put.

- "Učit ću čitati i pisati“, to je svrha odnosno opis aktivnosti.

- „Pravilno ću odgovoriti našest pitanja u radnoj bilježnici (DZ)“, to je cilj.

Važno je da cilj bude zapisan u sadašnjem vremenu, kao stanje kako je u točno određenom trenutku.

Ciljevi su bili napisani na dvjema razinama (Slika 1.): lakši i teži te su svakom cilju postavljeni kriteriji. Učenici su ih detaljno pročitali, zaokružili te odlučili koji će cilj slijediti. 
1. CILJ: Sam pročitam tekst. Kad zapnem, pitam učiteljicu. Nakon čitanja dopunim „kognitivnu mapu - kognitivni uzorak” s barem tri nove spoznaje. U DZ pravilno odgovorim na barem pet pitanja.

Kriterij za 1. cilj:

Pročitam tekst.

Kod nepoznatih riječi potražim pomoć učiteljice.

Pronađem i dopunim barem tri nove „spoznaje” drugom - upečatljivom bojom.

Pravilno odgovorim na barem pet pitanja u DZ.

2. CIL: Znam sam pročitati tekst. Nakon čitanja dopunim „kognitivnu mapu - kognitivni uzorak" s barem pet novih spoznaja. U DZ pravilno odgovorim na sva pitanja.

Kriterij za 2. cilj:

Brzo pročitam tekst.

Razumijem što piše u tekstu.

Pronađem i dopunim barem pet novih „spoznaja” drugom - upečatljivom bojom.

Pravilno odgovorim na sva pitanja u DZ i sastavim zaporku.

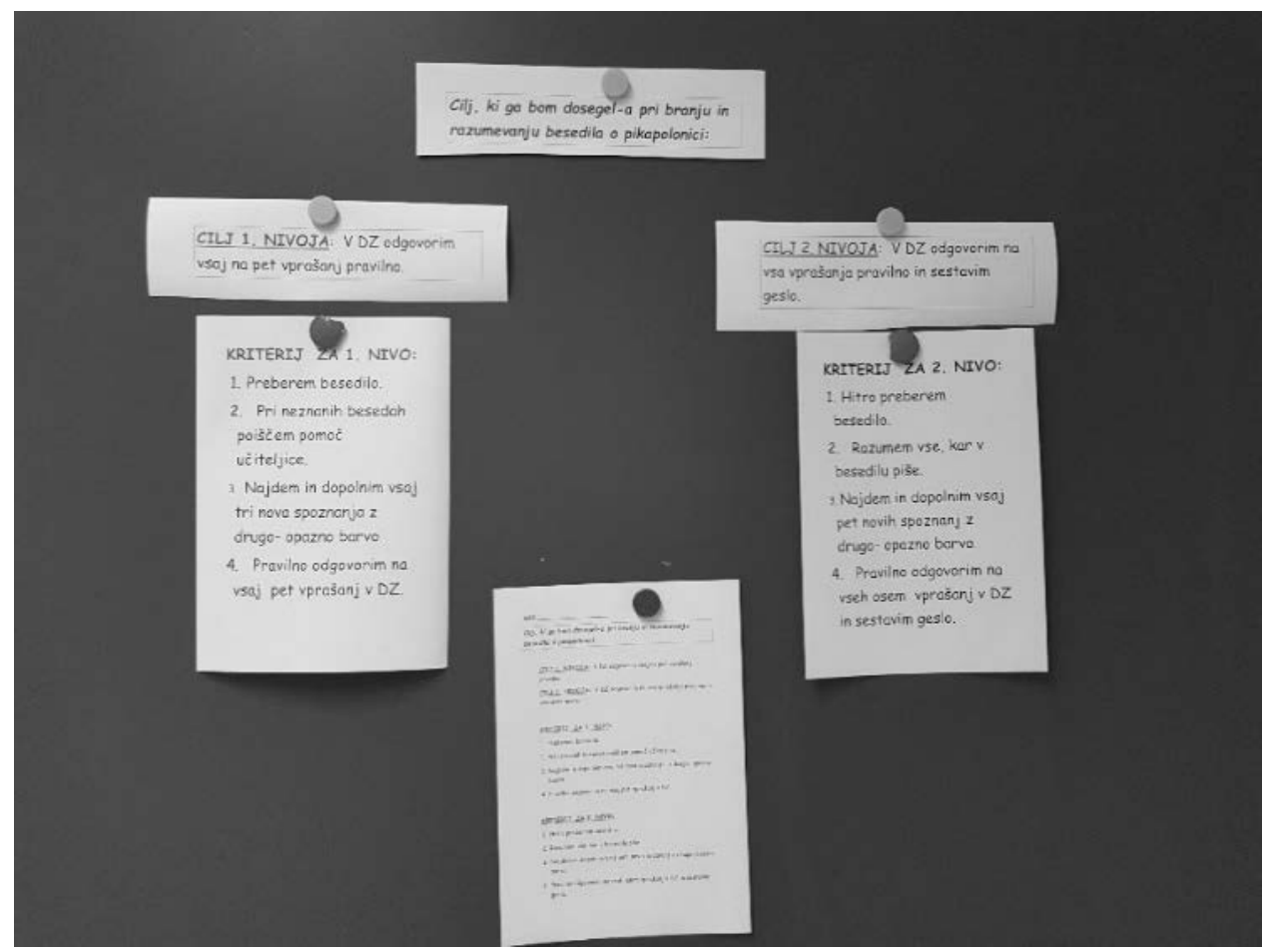

Slika 1. Ciljevi i kriteriji

Nakon pregleda ciljeva i kriterija slijedilo je dopunjavanje radnog plana gdje je već bila vidljiva diferencijacija (Slika2). 


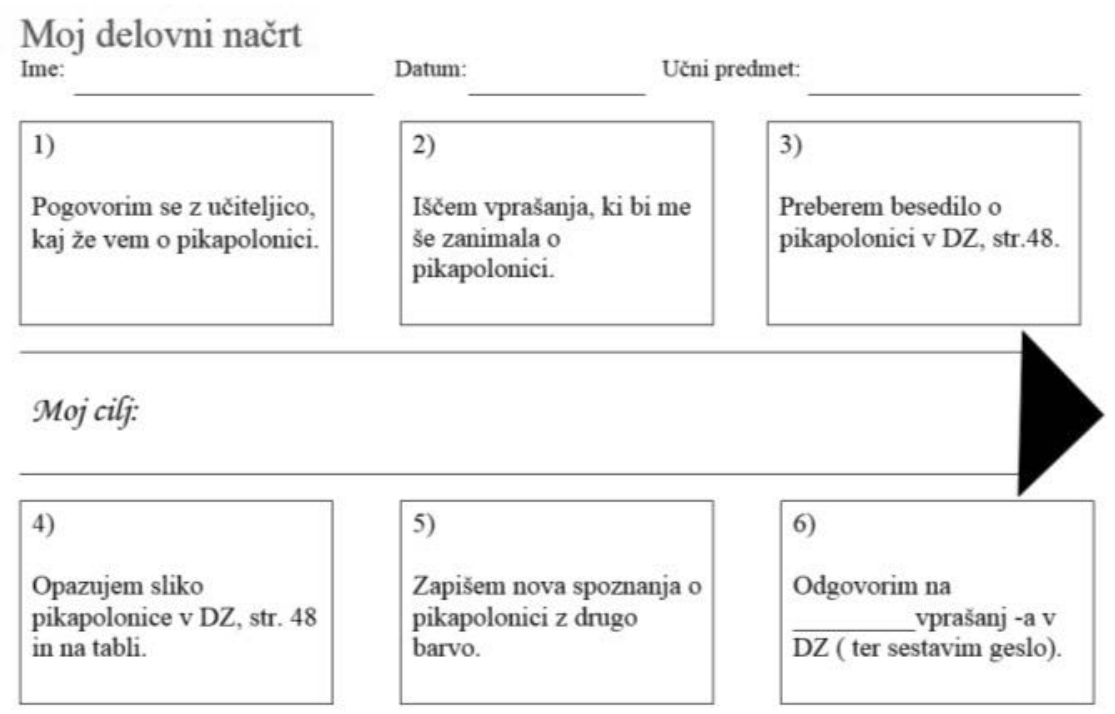

Slika 2. Plan rada za učenje o bubamari

Cijeli tijek zahtijevao je mnogo vremena na prvom stupnju. Naime, riječ je o procesu koji učenici tek moraju usvojiti. Ako kod učenika želimo poticati samoregulaciju učenja, važno je da razumiju ciljeve učenja što znači da ih učitelj mora preoblikovati. Oni pomažu učenicima razumjeti što će (na)učiti, usredotočiti se na aktivnost učenja, prepoznati koja će znanja, vještine i stavove razviti te kako preuzeti odgovornost za učenje i razviti odgovoran odnos prema učenju. $S$ ciljevima učenja upoznamo učenike na početku nastavne jedinice/teme te im se više puta vraćamo.

\section{Samostalno učenje o bubamari}

U okviru drugog stupnja učenici samostalno spoznaju neumjetnički tekst. Učitelj izvodi unutarnju diferencijaciju. Naime, učenici se s obzirom na postavljene ciljeve i planirani put podijele u grupe s obzirom na predznanje, sposobnosti i vještine.

Učenici se međusobno razlikuju u više čimbenika koji su ključni za učenje: predznanju, sposobnostima, mišljenjem o razumijevanju kvalitetnog učenja, stilu učenja, motivaciji te emocionalnom odnosu prema učenju. Za svakog je učitelja osnovni izazov na koji način uzeti u obzir sve navedene individualne razlike. Zbog toga je sljedeći dan u uvodu slijedilo provjeravanje predznanja tako da na list papira olovkom napišu i nacrtaju sve što već znaju o bubamari (Slika 3). 


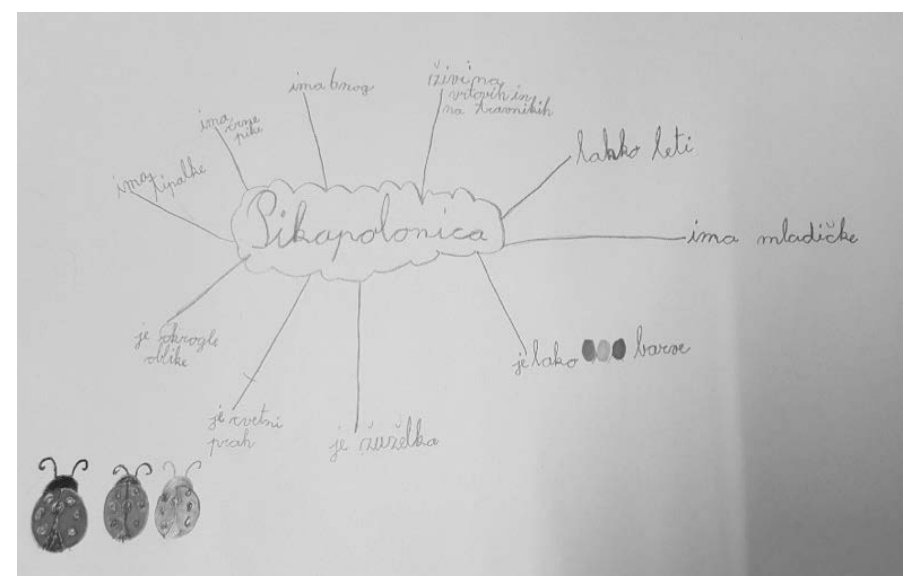

Slika 3. Zapisano znanjeo bubamari

Učenici su predstavili zapisano. Nakon toga su sastavljali pitanja o tome što ih još zanima o bubamari.

Pitanja su zapisivali na posebno pripremljene listove. Primjeri zapisanoga dani su na Slici 4.

Donosi li zaista bubamara sreću?

Gdje leže svoja jaja?

Koliko brzo leti?

Koliko dugo živi?

Zašto bubamara prekriva noge ako se uplaši?

Tko je njezin najgori neprijatelj?

Čime se hrani?

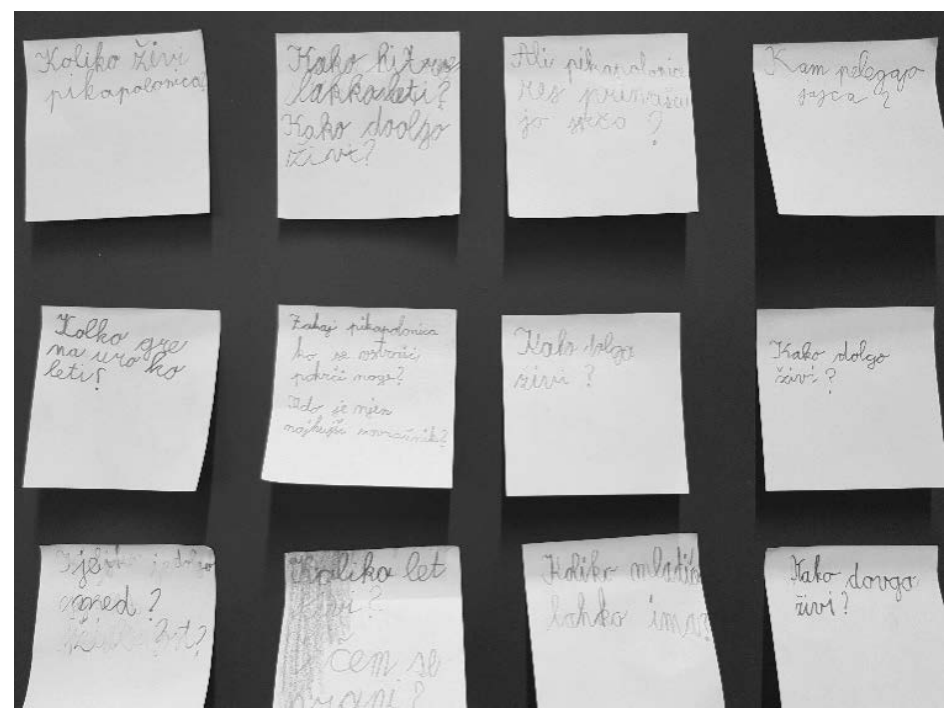

Slika 4. Zapisi o bubamari 


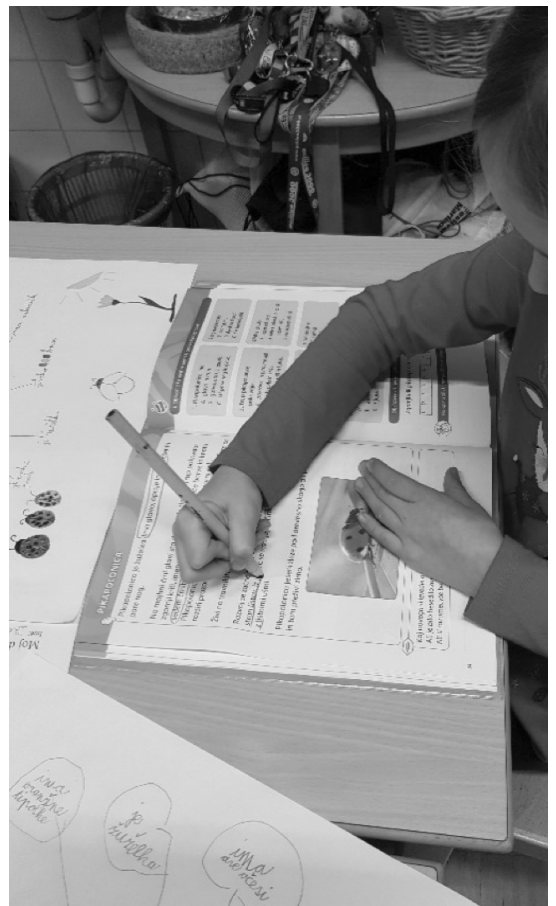

Slika 5. Čitanje i podcrtavanje

Slijedilo je čitanje teksta o bubamari. Učenici su u tekstu podcrtali nove spoznaje/riječi (Slika 5.).

Kognitivnu mapu dopunili su novim spoznajama te ih zapisali drugom bojom (Slika 6.).

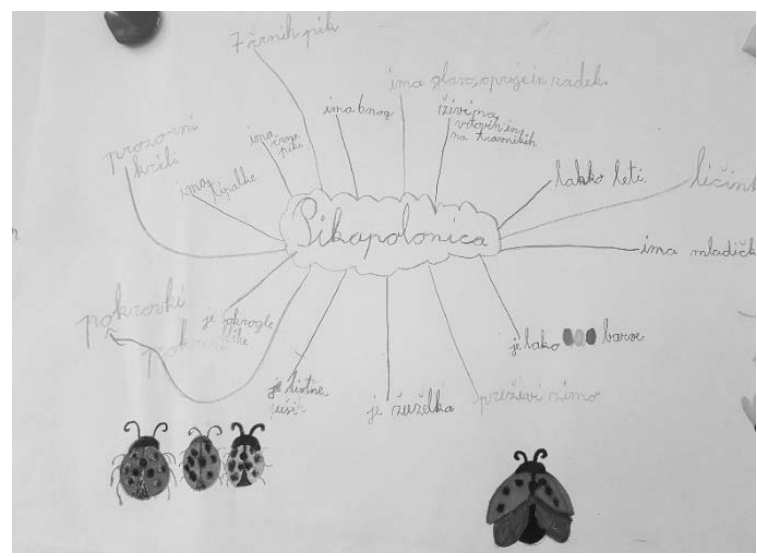

Slika 6. Dopunjena kognitivna mapa

Nakon postavljenog plana rada i ciljeva koje su odabrali prethodni dan, nastavili su svoj rad u radnim bilježnicama. Zbog toga što je riječ $s$ obzirom na školski uspjeh o vrlo uspješnoj grupi, neki su učenici kojima je cilj bila 1. razina, shvatili da su postavili preniske ciljeve te su ih željeli popraviti. Došli su do zaključka da mogu riješiti $i$ odgovoriti na sva pitanja u radnoj bilježnici i zapisati zaporku.

Za domaću zadaću mogli su odabrati jedno od postavljenih pitanja o bubamari koja smo odabrali na zajedničkom plakatu i pokušali potražiti odgovor na internetu, u knjižnici i dr.

Slijedila je samorefleksija učenja kada su učenici zapisali svoje ocjene o postignutim ciljevima na list za ocjenjivanje (Slika 7. i 8.).

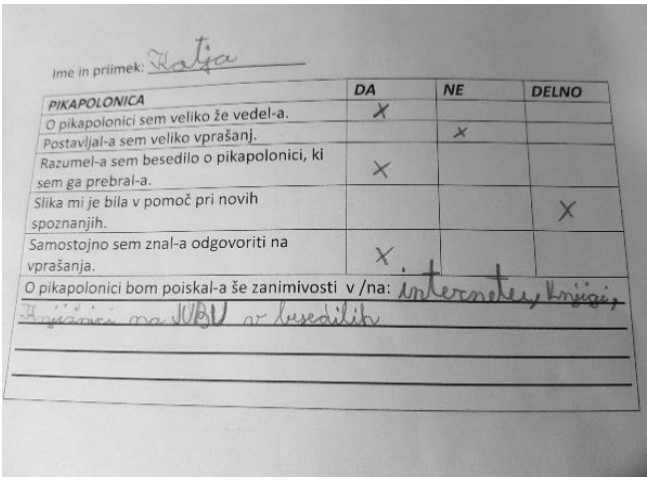

Slika 7. Primjer samorefleksije

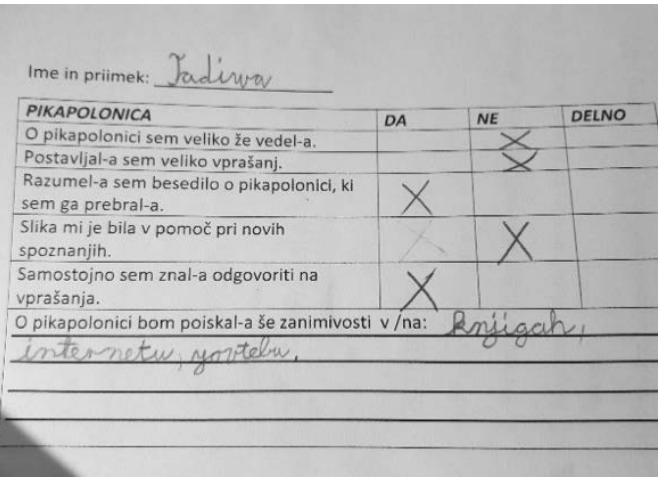

Slika 8. Primjer samorefleksije 
Tablica 1. Lista za samovrednovanje

\begin{tabular}{|l|c|c|c|}
\cline { 2 - 4 } \multicolumn{1}{c|}{} & DA & NE & DJELOMIČNOO \\
\hline O bubamari sam već mnogo toga znao/la. & & & \\
\hline Postavljao/la sam mnogo pitanja. & & & \\
\hline Razumio/la sam tekst o bubamari koji sam pročitao/la. & & & \\
\hline Slika mi je pomogla kod novih spoznaja. & & & \\
\hline Samostalno sam znao/la odgovoriti na pitanja. & & & \\
\hline O bubamari sam potražio još zanimljivosti u/na: & & \multicolumn{2}{|l|}{} \\
\hline
\end{tabular}

Učitelj je takvim načinom poučavanja u neprestanoj interakciji s učenicima (s pojedincem ili grupom). Omogućuje im da prate i vrednuju kvalitetu svog rada. Na taj način njihovo učenje postaje kvalitetnije i bolje osmišljeno. Kako bi učenik napredovao u postizanju ciljeva učenja, potrebno mu je samovrednovanje, povratne informacije učitelja i međuvršnjačko vrednovanje. Rezultati samovrjednovanja učitelju predstavljaju ishodište za daljnje planiranje nastave. Zbog toga je važno da učitelj stvara mogućnosti u kojima učenici osvještavaju svoj proces učenja.

\section{Zajednička refleksija}

Treći je stupanj namijenjen zajedničkoj refleksiji nakon završene etape učenja. Važno je da se učitelj koristi informacijama koje dobije u procesu samovrednovanja i vršnjačkog vrednovanja te u planiranju daljnjeg učenja. Učenici će učitelju vjerovati i ubuduće surađivati ako će primijetiti da se odaziva na njihove želje i potrebe.

Zbog toga su sljedeći dan učenici predstavili još zanimljivosti koje su pronašli o bubamari. Slijedila je zajednička refleksija učenja prema sljedećim pitanjima (Slika 9.).

\section{Što si novo naučio?}

- saznao sam da bubamara jede lisne uši

- puno sam naučio o bubamari

-saznao sam da bubamara ima kapke...

\section{Što nikada nećeš zaboraviti?}

- da bubamara donosi sreću

Kada bih imao više vremena, ja bih...

- promatrao bubamaru

- potražio više o bubamari

- potražio film o bubamari...

\section{Rado bih istražio više o...}

- točkicama

- sreći bubamare

- starosti...

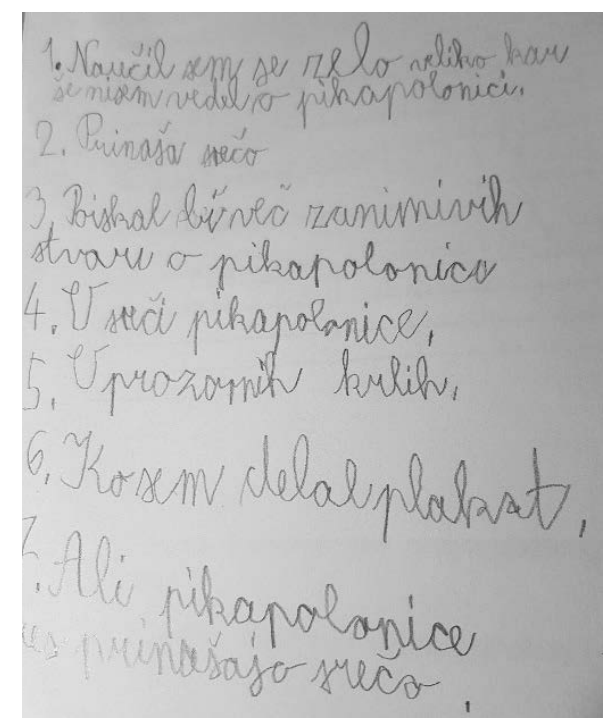




\section{To me navelo na razmišljanje o...}

- godinama

- krilima

- životu...

\section{Bio sam presretan kada...}

- sam toliko novoga naučio

- sam radio plakat

\section{Još uvijek imam sljedeće pitanje:}

- Koliko dugo raste?

- Donose li bubamare zaista sreću?

- Kako brzo leti?

- Zašto su crvene i narančaste boje?

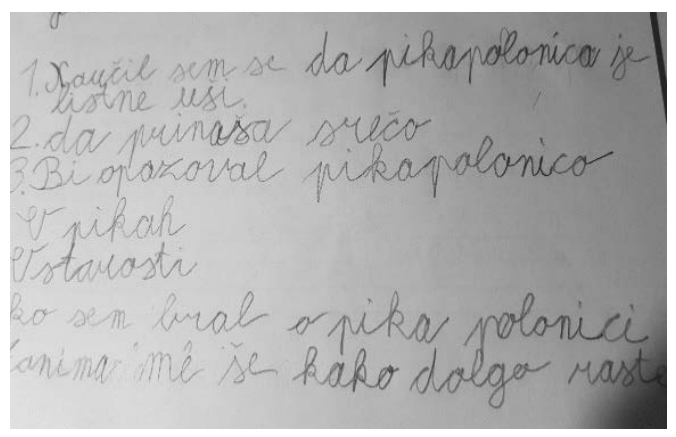

Slika 9. Zajednička refleksija

\section{ZAKLUUČAK}

Čitanje je ključni proces u kojem je važno da učenici razumiju pročitano i znaju iz teksta prepoznati poruku. Neki učenici pri tome imaju problem. Često se dogodi da je znanje učenika nakon čitanja još skromnije te imaju problem s razumijevanjem pročitanog. Kako bismo učenicima omogućili bolju i učinkovitiju obradu teksta, preporučuje se upotreba jednostavnih strategija čitanja koje doprinose boljem razumijevanju i pamćenju pročitanog teksta. S takvim strategijama čitanja i razumijevanja tekstova učenici su znatno više motivirani za daljnji rad i za čitanje s razumijevanjem. Potrebno je odrediti i osvijestiti pedagoški konceptualni okvir u koji ćemo smjestiti sva daljnja razvojna pedagoška razmišljanja na tu temu i razvijati obrazovnu praksu.

\section{LiTERATURA}

Grosman, M. (2006). Razsežnosti branja. Zaboljšo bralno pismenost. Ljubljana: Karantanija

Hus. V. (2002). Primerjava nekaterih didaktičnih dimenzij pouka spoznavanje okolja in spoznavanje narave in družbe v prvem razredu osnovne šole. Pedagoška obzorja, 17(3-4)

Cvetek, S. (2004). Kompetence v poučevanju in izobraževanju učiteljev. Sodobna pedagogika, 55, 144-160.

Kužnik, T. (2008). Teoretična izhodišča za načrtovanje sodobnih muzejev za otroke. Sodobna pedaggika, 59(2), 202-213.

Marentič Požarnik, B. (2000). Psihologija učenja in pouka. Ljubljana: DZS

Marentič Požarnik, B. i Cencič, M. (2004). Konstruktivizem - kažipot ali pot do kakovostnega učenja učiteljev in učencev? V: B. Marentič Požarnik (ur.). Konstruktivizem v šoli in izobraževanje učiteljev. Ljubljana. Center za pedagoško izobraževanje Filozofske fakultete in Slovensko društvo pedagogov.

Ošlak,T.(2009).Učinkovitost kompleksne bralne strategije VŽN v 3. razredu. Diplomski rad. Univerza v Mariboru : Pedagoška fakulteta.

Pečjak, S. (2000). Ali slišiš - Ali vidišs? Priročnik z vajami za razvoj metajezikovnega zavedanja. Trzin: Založbalzolit.

Plut Pregelj, L. (2005). Sodobna šola ostaja šola: kaj pa se je spremenilo? Sodobna pedagogika, 56(1), $16-32$. 
Strmčnik, F. (2003). Didaktične paradigme, koncepti in strategije. Sodobna pedagogika, 54(1), 8093.

\title{
Learning to Read and Strategies in Early Teaching
}

\begin{abstract}
The modern way to plan the teaching is based on communicative instruction. We stress the impact of the learning environment on the development of students' social competences. These competences begin to emerge in the early childhood. With the entry into primary school, they are visible as conspicuous personal characterisics. This article presents a practical example on how to use various learning strategies for acquisition of new knowledge. Within the school project Innovative pedagogical work sessions, which takes place each year at our school, we design, implement and evaluate innovative pedagogical approaches to teaching. We believe that educational work requires a combination of theory with practical efforts. In the past school year, we focused on learning how to read and teaching strategies.
\end{abstract}

Keywords: research oriented learning, learning environment, open class work, cross-subject class planning, peer group work.

\section{Lesen lernen und Strategien im Anfangsunterricht}

Zusammenfassung: Moderne Unterrichtsplanung basiert auf Kommunikationsunterricht. Wir betonen die Wichtigkeit der Lernumgebung, in der die sozialen Kompetenzen der Schüler gestaltet werden. Diese beginnen sich in der frühen Kindheit zu entwickeln, und beim Schuleintritt äußern sie sich schon als bemerkbare Persönlichkeitseigenschaften. Der Artikel beschreibt ein Beispiel aus der Praxis, wie verschiedene Lernstrategien im Unterricht eingesetzt werden können, um neues Wissen zu erlangen. Im Rahmen des Projekts Innovative pädagogische Workshops der Brüder Polančičev Grundschule aus Maribor, planen, implementieren und bewerten wir jedes Jahr innovative Ansätze für die pädagogische Praxis. Wir glauben, dass theoretische und praktische Erfahrungen in der pädagogischen Arbeit miteinander verknüpft werden müssen. Im vergangenen Schuljahr haben wir besonderen Wert auf das Lesenlernen sowie auf die Strategien im Anfangsunterricht gelegt.

Schlüsselwörter: Forschungslernen, Lernumgebung, offener Unterricht, interdisziplinäre Unterrichtsplanung, altersübergreifende Zusammenarbeit 